\title{
MITÄ RYHMÄVIESTINNÄN TEORIAT VOISIVAT TARJOTA VERKOSTOJOHTAMISELLE?
}

\author{
Riitta Vanhatalo
}

\section{TIIVISTELMÄ}

Verkostoitumisesta tuli 1990-luvulla Suomessa trendi. Sen myötä verkosto on yleistynyt yhteistyön muotona. Verkostoilta odotetaan paljon, mutta toiminnan laatu ja tulokset eivät vastaa aina odotuksia. Toisaalta toimintatapojen kehittämiseen ei ole riittävästi panostettu. Artikkelissa tarkastellaan verkostojohtamista viestinnän ja vuorovaikutuksen näkökulmasta. Näkökulma on luonteva, koska koko verkoston olemassaolo perustuu toimijoiden henkilökohtaisiin suhteisiin ja vuorovaikutukseen. Lisäksi johtaminen on viestintää ja viestintäosaamisen merkitys kaikessa johtamisessa on kasvanut. Aluksi artikkeli avaa näkökulmia, jotka luovat kuvaa siitä, mitä tekijöitä verkostojohtamisessa on hyvä ottaa huomioon. Näitä näkökulmia peilataan kahteen ryhmäviestinnän teoriaan: strukturaatioteoriaan ja funktionaaliseen teoriaan. Artikkeli nostaa yhdeksi verkostojohtamisen haasteeksi toimijoiden tasavertaisuuden ihanteen, koska johtaminen koetaan toisinaan uhkana verkoston toimijoiden tasavertaisuudelle. Strukturaatioteorian mukaan erilaiset ryhmäilmiöt rakentuvat vuorovaikutusprosesseissa. Sen mukaan verkoston rakenne ja toimintatavat ovat suoraan suhteessa verkoston vuorovaikutukseen. Esimerkiksi tasavertaisuuden näkökulmasta johtajan ja muiden toimijoiden roolit syntyvät vuorovaikutuksessa ja siten ne kuvaavat verkoston todellisuutta. Funktionaalinen teoria tarkastelee johtamista toimintoina, jotka edistävät tai vaikeuttavat tavoitteiden saavuttamista. Funktionaalinen teoria korostaa johtajan kahtalaista haastetta: toisaalta vahvistaa koheesiota, toisaalta varmistaa toimiva päätöksentekoprosessi. Kun strukturaatioteoria tarkastelee vuorovaikutuksen suhdetta verkoston rakenteeseen ja toimintaan, funktionaalinen teoria tarkastelee vuorovaikutuksen suhdetta verkoston tuloksellisuuteen. Artikkelissa todetaan, että kumpaakin teoriaa voidaan soveltaa verkostojohtamisen tutkimuksessa, mutta niiden lähtökohdat ovat erilaiset.

Asiasanat: johtaminen, ryhmäviestintä, verkosto 


\section{JOHDANTO}

Yhteistyön tarve on kasvanut yhteiskunnassamme. Se on vaikuttanut myös verkostoitumisen yleistymiseen. Verkostot ovat yleistyneet niin työelämässä, yritysmaailmassa, eri organisaatioiden yhteistyössä kuin kansalaistoiminnassakin. Yhdistysten luvatuksi maaksi luonnehditussa Suomessa 1990-luvulta alkaen kansalaistoiminnan taustalla ovat olleet entistä useammin yhdistyksiä joustavammat verkostot (Rasimus 2006, 17-19). Verkostoituminen voidaan nähdä yksilön näkökulmasta sosiaalista pääomaa tuottavana sosiaalisten suhteiden rakentamisena, jota nykyaikana arvostetaan. Tärkeää on, keitä ihmisiä tunnet ja missä asemassa verkostossa olet (Pehkonen 2004, 47). Myös maantieteellisiä alueita on kuvattu verkostoituneisuuden asteen mukaan. Verkostoituminen nähdään tässäkin tapauksessa vahvuutena ja vetovoimatekijänä (Linnamaa 2004, 59-60). Yritysten kyvyn toimia verkostoissa uskotaan edistävän niiden kilpailukykyä (Ritter \& Gemünden 2003, 746-754).

Verkostoyhteistyö on osoittautunut kuitenkin monin tavoin haasteelliseksi, ja ennestäänkin tutut yhteistyökumppanit joutuvat verkostomaista työskentelyä aloittaessaan tarkistamaan roolejaan ja toimintatapojaan (Virtanen 1999, 38-44). Esimerkiksi talouden verkostot edellyttävät tehokasta ja nopeaa informaation vaihtoa kaikkien osapuolten kesken (Hannus 1997, 62). Voi olla myös yllättävää havaita, että verkostomainen yhteistyö edellyttää kompromisseja, jotka eivät välttämättä vastaa täysin kenenkään näkemyksiä (Virkkala 2002, 29).

Verkostojen toimintatapoihin ei ole välttämättä käytännössä kiinnitetty paljonkaan huomiota. Niiden on uskottu tuottavan automaattisesti hyviä yhteistyön hedelmiä. Joskus näin on voinut tapahtuakin. Yhteistyö on saattanut esimerkiksi muuttua joustavammaksi. Verkostousko ja verkostoväsymys ovat kuitenkin esimerkkejä verkostotoiminnan haasteista. Jos verkostousko johtaa siihen, että verkoston uskotaan tekevän toiminnasta automaattisesti tehokasta, ei toiminnan kehittämiseen kiinnitetä riittävästi huomiota. Laajamittainen verkostoituminen voi aiheuttaa myös sen, ettei verkostoihin jakseta panostaa. Verkostoväsymys voi uhata ennen kuin verkostoja on kyetty vielä kunnolla hyödyntämään. (Linnamaa 2004, 209-210.) Esimerkiksi näihin ongelmiin liittyvät monet verkostoyhteistyön heikkoudet. Verkostojohtamista on esitetty välineeksi verkostoyhteistyön kehittämiseen (Linnamaa 2004; Uusikylä 1999; Virtanen 1999).

Verkostojohtaminen määritellään tässä artikkelissa toiminnaksi, jolla edistetään vuorovaikutusprosesseja ja suunnataan verkostoa kohti päämääriä (Kickert, Klijn \& Koppenjan 1997; Linnamaa 2004, 85-211). Sen näkemyksen mukaan tärkeintä verkostojohtamisessa on edistää vuorovaikutuksen sujuvuutta ja yhteisten tavoitteiden toteutumista. Verkostojohtamiseen kuuluu siten sekä ihmisten että asioiden johtaminen.

Verkoston koko olemassaolo perustuu toimijoiden välisiin henkilökohtaisiin suhteisiin ja vuorovaikutukseen. Se siis poikkeaa organisaatiosta, jonka toiminta jatkuu sovitun työnjaon puitteissa ainakin osittain, vaikka keskinäinen vuorovaikutus katkeaisi. Verkosto muistuttaakin enemmän tehtäväkeskeistä 
ryhmää siinä, että yhteistoiminta on väljästi organisoitunutta ja jäsenten väliset suhteet ja vuorovaikutus ratkaisevat toiminnan tulokset. Ryhmäviestinnän tutkimuksella on pitkä historia verrattuna verkostoilmiöön. Tutkimus on tuottanut menetelmiä ja teoriaa vuorovaikutuksen analysointiin. Ryhmäviestinnän teoriat voivat tuoda uusia näkökulmia tätä kautta myös verkostojohtamisen tutkimukseen.

Artikkelissa avataan neljä näkökulmaa, jotka lisäävät ymmärrystämme siitä, mistä puhutaan kun puhutaan verkostojohtamisesta. Aluksi tarkastellaan verkostoa kontekstina, mikä kuvaa niitä erityispiirteitä ja haasteita, joita johtamiseen kohdistuu verkostoympäristössä. Koska verkoston ihanteeseen liitetään vahvasti ajatus toimijoiden keskinäisestä tasavertaisuudesta, toiseksi tarkastellaan lyhyesti tasavertaisuutta verkostojohtamisen haasteena. Kolmantena näkökulmana pohditaan johtamisen ja viestinnän suhdetta. Neljäs näkökulma valottaa kasvokkaisviestinnän ja teknologiavälitteisen viestinnän piirteitä. Verkostojohtamisen kannalta on kiinnostavaa, miten eri viestintäfoorumeita voi hyödyntää ja miten ne vaikuttavat verkoston toimintaan. Foorumi viittaa tässä yhteydessä niihin fyysisiin tai virtuaalisiin tiloihin ja tilanteisiin, joissa viestintä ja vuorovaikutus on mahdollista.

Verkostojohtamisen näkökulmia peilataan kahteen klassiseen ryhmäviestinnän teoriaan eli strukturaatioteoriaan ja funktionaaliseen teoriaan. Alun perin sosiologi Anthony Giddensin (Giddens 1983) kehittämä strukturaatioteoria on ollut vaikuttamassa voimakkaasti ryhmäviestinnän tutkimukseen ja teoriaan 1980-luvulta lähtien. Se on ollut eräänlainen metateoria, jolla on ollut paljon selitysvoimaa viestinnän eri ilmiöille. Poole, Seibold ja McPhee toivat strukturaatioteorian ryhmäviestinnän tutkimukseen (Poole 1999, 48-50). Strukturaatioteoria korostaa vuorovaikutuksen merkitystä erilaisten ryhmäilmiöiden rakenteen ja toimintatapojen synnyssä. Funktionaalinen teoria puolestaan näkee viestinnän ja vuorovaikutuksen välineenä ryhmän ja sen jäsenten pyrkiessä tuloksiin, päätöksiin tai ongelmanratkaisuihin (Gouran \& Hirokawa 1996, 55). Strukturaatioteoria ja funktionaalinen teoria on valittu, koska ne ovat jo osoittautuneet monipuolisesti sovellettaviksi. Niissä voi olla potentiaalia uusiin sosiaalisiin järjestelmiin ja ryhmäilmiöihin, jollaisena verkostonkin voi nähdä. Artikkelin tavoitteena on arvioida näiden teorioiden soveltuvuutta verkostojohtamisen tutkimukseen neljän edellä kuvatun näkökulman valossa.

\section{NÄKÖKULMIA VERKOSTOJOHTAMISEEN}

\section{Verkosto kontekstina}

Verkostoituminen on ollut ihmiselle ikiaikaisesti luontainen tapa luoda suhteita ja tehdä yhteistyötä. Vaikkei verkoston käsitettä tunnettu eikä käytetty, verkostoitumalla ihmiset ovat ennenkin luoneet esimerkiksi uusia ystävyys- ja kauppa- 
suhteita sekä levittäneet jopa maasta toiseen uusia tapoja ja tietoja. Verkostoilla on ollut siten keskeinen asema ihmiskunnan historiassa. (Hakanen, Heinonen \& Sipilä 2007, 9; McNeill \& McNeill 2006, 19-26.)

Verkostoitumistrendin synty voidaan sijoittaa Suomessa 1990-luvulle (Ruostetsaari 2003, 224). Jo 1980-luvun lopulla esimerkiksi sosiaalityön alalla puhuttiin verkostoitumisen tärkeydestä (Virtanen 1999, 36). Sittemmin verkostoitumisesta alettiin puhua yleisesti tehokkaana ja nykyaikaisena yhteistyön muotona. Taustalla oli lisääntynyt yhteistyön tarve ja uusien joustavampien yhteistyömuotojen etsintä. Ilmiöön ovat vaikuttaneet myös yhteiskunnalliset muutokset ja tietoverkkojen kasvu (Mattila \& Uusikylä 1999, 7). Uutta vanhaan verkostoitumiseen verrattuna onkin erityisesti uuden teknologian hyödyntäminen (Castells 1996).

Verkoston jäsenet jakavat saman mielenkiinnon kohteen, ja verkosto muodostaa suhteellisen pysyvän yhteisön, jossa voidaan vaihtaa kokemuksia, mielipiteitä ja tietoa sekä vaikuttaa tärkeinä pidettyihin asioihin. Verkostot voivat koostua joustavasti erilaisista toimijoista, joiden kokemuspiiri ja osaaminen muodostavat koko verkoston potentiaalin. Siinä piilee mahdollisuus monipuoliseen ja kokonaisvaltaiseen asioiden käsittelyyn sekä uusiin, luoviin ratkaisuihin.

Verkostoitumisilmiön yleistymistä kuvannee hyvin se, miten verkoston käsite on levinnyt tarkoittamaan mitä erilaisimpia asioita eli verkosto käsitteenä ei ole selkeä ja yksiselitteinen (Niemi-Iilahti 2002, 214; Ruostetsaari 2003, 224). Verkostoilla on kuitenkin yleisiä, yhteisiä piirteitä, joiden varassa ne voidaan tunnistaa verkostoiksi. Verkostoa luonnehtivia piirteitä ovat vakiintumattomuus, joustavuus, oppiminen ja vaihtaminen, esimerkiksi tiedon vaihto (Karriker 2005,56 ). Verkoston vuorovaikutussuhteita ja kontakteja voidaan arvioida myös tiheyden, keskeisyyden ja keskittyneisyyden mukaan (Huotari, Hurme \& Valkonen 2005, 19-20). Joskus korostetaan myös sitä, miten verkostosuhteet perustuvat keskinäisen tuen ja jokaiselle toimijalle syntyvän hyödyn varaan (Linnamaa 2004, 208).

Yleisimmillään verkosto nähdään kokonaisuutena, jossa kaksi tai useampi itsenäinen toimija ovat lähempänä toisiaan verkoston kautta kuin ilman sitä (Linnamaa 2004, 50-51). Määrittelen verkoston eriasteisesti ja eri tavoin vakiintuneiksi sosiaalisiksi suhteiksi toisistaan riippuvaisten toimijoiden välillä, jotka ovat organisoituneet yhteisen intressin ympärille (Linnamaa 2004, 51, 174). Määritelmä sitoo samalla verkoston tiukasti riippuvaiseksi vuorovaikutuksesta. Ilman toimijoiden välistä vuorovaikutusta verkostoa ei ole olemassa. Niin kauan kuin toimijat viestivät keskenään, he ovat osa verkostoa (Schaap \& Van Twist 1997, 73). Verkostojen moninaisuudesta johtuen tarkempi tarkastelu edellyttää kuitenkin aina verkostotyypin määrittelyä.

Verkostoja on pyritty jäsentämään monin tavoin. Yleisellä tasolla ne on voitu jakaa fyysisiin, taloudellisiin ja sosiaalisiin verkostoihin. Fyysisiin verkostoihin lukeutuvat esimerkiksi tietoverkot (Castells 1996). Taloudellisia verkostoja 
tutkivat ovat puolestaan kiinnostuneita taloudellisten toimijoiden verkostosuhteista ja niin sanotusta verkostotaloudesta (Hautamäki 2001). Verkostotalousteoriat näkevät verkostot kolmantena tapana järjestää yhteistyö hierarkioiden ja markkinoiden lisäksi. Sosiaalisia verkostoja tutkittaessa erityisenä mielenkiinnon kohteena on ollut suhteiden rakenne.

Suomalaisessa verkostotutkimuksessa on tyypitelty esimerkiksi alueellisen kehittämisen verkostoja. Tavoitteellinen verkosto on perustettu tietyn yhteisen tavoitteen aikaansaamiseksi. Etsintäverkosto keskittyy informaation ja kokemusten vaihtoon sekä uusien innovaatioiden etsimiseen. Tukiverkosto tai kollegaverkosto tähtää saman alan ihmisten kokemusten vaihtoon ja jäsentensä oman työn kehittämiseen. Torjuntaverkosto tai edunvalvontaverkosto pyrkii tilanteen mukaan joko torjumaan jonkin uhan tai saavuttamaan jonkin edun yhteistyön avulla. Kansalaisvaikuttamisen verkosto on niin ikään perustettu jonkin tietyn tavoitteen saavuttamiseksi. Kuudentena verkostotyyppinä on erotettu investointiverkosto, joka on perustettu suurten investointien toteuttamiseksi. Käyttötarkoituksen mukaan verkostoja on jaoteltu myös potentiaalisiin ja strategisiin verkostoihin. (Linnamaa 2004, 51-52.)

Hallintotieteilijöiden mielenkiinto verkostotutkimuksessa on keskittynyt muun muassa siihen, mikä on verkostokäsitteen suhde organisaation käsitteeseen. Toisin sanoen verkostoa on verrattu organisaatioon etsien eroavaisuuksia ja yhtäläisyyksiä. Verkosto eroaa organisaatiosta suhteiden formalisoinnin asteen perusteella sekä toiminnan koordinoinnin luonteen perusteella. Tämän näkemyksen mukaan verkosto ei ole organisaatio, mutta verkostosta voi kehittyä organisaatio, mikäli yhteistoiminnan piirteet muuttuvat ja erottavia tekijöitä ei enää tunnisteta. Tämä määrittely on merkityksellistä, jos verkosto halutaan säilyttää erillisenä yhteistoiminnan organisoitumisen muotona. (Niemi-Iilahti 2002, 214.)

Ryhmäviestinnän viitekehyksessä on relevanttia verrata verkostoa ryhmään ja hakea määrittelyn rajoja myös suhteessa ryhmän käsitteeseen. Ryhmän voi määritellä yksinkertaisimmillaan käsittämään kahta tai useampaa yksilöä, jotka tuntevat kuuluvansa samaan sosiaaliseen kategoriaan (Brown 2000,3). Useimmiten ryhmän minimikoko on kuitenkin kolme jäsentä (Huotari, Hurme \& Valkonen 2005,22 ). Ryhmän käsitteeseen on liitetty myös vuorovaikutuksen taso eli ryhmän jäsenet ovat vuorovaikutuksessa keskenään ja vaikuttavat vuorovaikutuksen kautta toinen toisiinsa. Ryhmällä katsotaan olevan myös yhteinen tavoite, jolloin yhden saavuttaessa tavoitteen kaikki ryhmän jäsenet saavuttavat sen, mutta toisaalta kaikki ryhmän jäsenet myös vastaavat toiminnan tuloksista (Galanes, Adams \& Brilhart 2004, 8-11; Huotari, Hurme \& Valkonen 2005, 15). Verkostoa ja ryhmää yhdistää, että molemmissa jäsenet kokevat yhteenkuuluvuutta. Lisäksi myös verkostossa jaetaan yhteinen tavoite. Mikäli tavoitteesta on erimielisyyttä, siitä voi muodostua verkostoa hajottava tekijä. Tärkein ryhmää ja verkostoa erottava tekijä on ryhmän tai verkoston koko. Ryhmässä jokainen jäsen tuntee toisensa ja on vuorovaikutussuhteessa jokaisen ryhmän jäsenen 
kanssa ainakin periaatteessa, mikä pätee erityisesti pienryhmässä. Verkostossa toimijoiden määrä voi kohota satoihin tai tuhansiin. Isossa verkostossa toimijoiden määrä rajoittaa vuorovaikutusta. Periaatteessa jokainen voi olla vuorovaikutussuhteessa kaikkien toimijoiden kanssa, mutta käytännössä kukaan ei todennäköisesti ole vuorovaikutuksessa jokaisen muun toimijan kanssa. Kun pienryhmiin sovelletaan verkostonäkökulmaa, myös ryhmän rakenteen voi havaita koostuvan laajemmasta joukosta ihmisten ja yhteisöjen välisiä suhteita (Katz ym. 2004, 324). Verkostonäkökulma voi ryhmiä tutkittaessa laajentaa esimerkiksi näkemystä ryhmän jäsenten verkostosuhteiden ja ryhmän tuloksellisuuden yhteydestä toisiinsa (Katz ym. 2004, 325).

\section{Verkoston toimijoiden keskinäinen tasavertaisuus}

Mielikuvaan ihanteellisesta verkostosta liitetään usein ajatus toimijoiden keskinäisestä tasavertaisuudesta (Linnamaa 2004). Käsitteenä toimija viittaa ajatukseen verkoston jäsenen aktiivisesta toiminnasta osana verkostoa, ei pelkästään nimellisestä osallisuudesta verkostoon (Huotari, Hurme \& Valkonen 2005, 19; Schaap \& Van Twist 1997, 72). Artikkelissa verkosto nähdään aktiivisten toimijoiden yhteistyön muotona, jossa toimijat haluavat osallistua ja vaikuttaa päätöksentekoon sekä saavuttaa yhdessä asetettuja tavoitteita. Sen vuoksi artikkelissa käytetään toimija-käsitettä, joka kuvastaa myös verkoston luonnetta.

Verkostoja on pidetty perinteisesti toimintatapana, jossa ei ole hierarkioita eikä kukaan johda ketään (Linnamaa 2004, 14). Tasavertaisuudella tarkoitetaan sitä, että verkostossa kukaan toimijoista ei ole periaatteessa muiden yläpuolella ja että jokaisella toimijalla on ainakin periaatteessa samanlaiset osallistumismahdollisuudet verkoston toimintaan ja vaikuttamiseen verkostossa. Tämä näkökulma nostetaan erikseen esille, koska joissakin verkostoissa ajatellaan, että johtaminen on uhka tasavertaisuudelle ja verkoston luovuudelle (Linnamaa 2004, 14, 213).

Toisaalta on kuitenkin todettu, että jos valta-, työnjako- ja vastuukysymykset jäävät kokonaan sopimatta, verkostosta voi tulla löyhä ja epämääräinen (Virtanen 1999, 40). Liian tiukat normit voivat puolestaan muuttaa verkoston hierarkkiseksi ja verkostomaisuus häviää (Uusikylä 1999, 61).

Vaikuttaa siltä, että tasavertaisuus ja demokraattiset osallistumis- ja vaikuttamismahdollisuudet ovat tärkeä tekijä verkoston toimijoille. Sen vuoksi ne kannattaa huomioida myös tarkasteltaessa verkostojohtamista.

\section{Johtaminen on viestintää}

Yleisesti johtamisen toimintaympäristön muutokset, esimerkiksi organisaatioiden hierarkioiden madaltuminen, ovat lisänneet entisestään vuorovaikutuksen merkitystä johtamisessa (Hujala 2008, 13). Verkostojohtamiseen tämä pätee aivan erityisesti, koska koko verkosto rakentuu vuorovaikutussuhteiden varaan. Pitkään johtamisessa on yleisesti erotettu kaksi osa-aluetta: management eli asi- 
oiden johtaminen ja leadership eli ihmisten johtaminen (Kotter 1996, 23). Tässä artikkelissa verkostojohtaminen kattaa sekä ihmisten että asioiden johtamisen. Nykyisin johtamiskirjallisuudessa usein kyseenalaistetaan ylipäätään tällainen kahtiajako (Viitala 2004), koska niiden nähdään pikemminkin limittyvän toisiinsa eikä tässäkään yhteydessä ole mielekästä erottaa niitä toisistaan. Verkostojohtamisen voi kuitenkin perustellusti todeta painottuvan ihmisten johtamiseen, koska ihmiset eli verkoston toimijat ovat koko verkoston tärkein resurssi ja myös asioita johdetaan yhdessä toisten toimijoiden, usein eri alojen asiantuntijoiden, kanssa.

Monet johtamisen edellyttämät taidot ovat säilyttäneet merkityksensä parin viime vuosikymmenen aikana. Viestintäosaamisen merkitys johtamisessa on jopa kasvanut tultaessa 2000-luvulle. Viestintäteknologian kehitys on tehostanut ja nopeuttanut viestintää, mutta samalla se edellyttää uudenlaisia viestintätaitoja. Samalla, kun hallinnollisen osaamisen merkitys on vähentynyt, ihmisten välisiin suhteisiin sekä informaation ja ideoiden viestimiseen liittyvät taidot ovat kasvattaneet merkitystään. (Gentry ym. 2008.)

Myös osaamisen johtaminen ja tietojohtaminen eli tiedon luomisen edistäminen edellyttävät viestintää (Huotari, Hurme \& Valkonen 2005; Vanhala, Laukkanen \& Koskinen 2002). Luovat prosessit pitävät sisällään sekä tiedon hankkimista itselle ja koko yhteisölle (esimerkiksi verkostolle) että tiedon jakamista ja olemassa olevan tiedon soveltamista uuden tiedon tuottamiseksi. Verkoston johtamiseen kuuluu edellytysten luominen toimivalle vuorovaikutukselle, joka edistää prosesseja (Kickert \& Koppenjan 1997). Viime aikoina huomio on kohdistunut johtajaan myös fasilitoijana, jolloin vähäinen viestintä voi olla esteenä johdettavan yksikön uuden oppimiselle (Amy 2008, 227).

Ryhmissä aktiiviset johtajat tuovat esille ratkaistavia ongelmia ja kysyvät muiden mielipiteitä ja tietoja useammin kuin muut ryhmän jäsenet. Heidän vuorovaikutuksessaan korostuvat teot, joilla viedään prosessia eteenpäin ja aktivoidaan muita ryhmän jäseniä osallistumaan (Pavitt 1999, 320). Myös hajautetuissa tiimeissä johtajan odotetaan aktivoivan muita tiimin jäseniä viestintään (Sivunen 2007, 197).

Verkostot näyttävät edellyttävän avointa informaation jakamista, sitoutumista yhteistyöhön, päämäärien samansuuntaisuutta, luottamusta ja sovittua työnjakoa, jotta ne toimisivat tehokkaasti. Koska verkostossa toimijat ovat yhtä kuin verkosto ja samalla verkoston tärkein resurssi, huomio kiinnittyy myös siihen, ketkä ovat mukana ja ketkä eivät. Verkostojohtamisella pyritään rakentamaan verkostoa niin, että uusia toimijoita on mahdollista saada verkostoon, ja aktivoimaan heitä vuorovaikutukseen. Verkoston johtajan pitää myös varmistaa, että yhteistyölle ja vuorovaikutukselle on riittävästi foorumeita. Huomiota on kiinnitettävä lisäksi siihen, miten vuorovaikutus ja keskustelu foorumeilla jäsentyvät. (Linnamaa 2004, 69-83, 210-212.)

Verkoston päätöksenteossa pyritään päätökseen yhteisen myöntymisen avulla (Niemi-Iilahti 2002, 216). Yksimielinen päätöksenteko verkostossa edel- 
lyttää muutaman kriittisen tekijän toteutumista. Ensinnäkin se edellyttää toimijoiden keskinäistä luottamusta, jolloin uskalletaan ilmaista mielipiteet suoraan ja rehellisesti. Johtajan odotetaan helpottavan verkoston toimijoiden työskentelyä. Lisäksi aikaa tulee olla riittävästi, jotta eri näkemykset ehtivät tulla esille ja niitä myös ehditään arvioida. Informaation jakaminen on tärkeää. Toimijat tarvitsevat kaiken olemassa olevan tiedon ja aikaa perehtyä siihen ennen päätöksentekoa. (Pennington 2005, 163-164.)

\section{Kasvokkaisviestinnän ja teknologiavälitteisen viestinnän merkitys verkostossa}

Verkostossa viestintää voi olla eri foorumeilla. Tässä artikkelissa käytetään viestintäfoorumin käsitettä viestintäkanavan sijaan. Viestintäkanava on tuttu vanhasta viestinnän mallista, jossa käsitteellisesti erotetaan viestin lähettäjä ja vastaanottaja. Mallissa viestin lähettäjää ja vastaanottajaa yhdistää viestintäkanava, jonka kautta viesti saavuttaa vastaanottajan. Malli perustuu mekanistiseen ja lineaariseen näkemykseen viestinnästä. Toisaalta esimerkiksi Sivunen (2007, 154-158) on edelleen käyttänyt viestinnän kanava -käsitettä tarkoittaessaan tiedon siirtymisen reittejä hajautetuissa tiimeissä. Sivunen jakaa viestinnän kanavat visuaalisiin, auditiivisiin ja audiovisuaalisiin kanaviin. Samalla hän on korostanut käsitteellistä eroa viestinnän tapoihin (esimerkiksi kirjoittaminen, puhuminen) ja viestintävälineeseen (esimerkiksi sähköposti, keskustelufoorumi). Organisaatioiden vuorovaikutustilanteita on kutsuttu myös viestinnän areenoiksi (Stacey 1991, Aulan 1999, 151 mukaan). Tässä artikkelissa viestintäfoorumi tarkoittaa fyysistä tai virtuaalista tilaa tai tilannetta, jossa viestintä ja vuorovaikutus on mahdollista. Se mahdollistaa myös ei-lineaarisen ja monimutkaisen viestintäprosessin ja vuorovaikutuksen.

Verkostojen viestinnälle on tyypillistä teknologian hyödyntäminen. Pienessä verkostossa voi olla enemmänkin kasvokkaisviestintää, mutta mitä isommasta verkostosta on kysymys, sitä todennäköisemmin sen sisäinen viestintä edellyttää erilaisten sähköisten viestintäteknologioiden käyttöä. Teknologiavälitteisen viestinnän piirteet on otettava huomioon myös verkostojohtamisessa. Toimintatavat on muokattava teknologioiden mukaan, jotta niistä saadaan paras hyöty. On todettu, että kaikkia viestintäteknologioita voi käyttää vuorovaikutteisesti tai olla käyttämättä (Matikainen 2006, 179).

Internetin ja viestintäteknologioiden käyttöön on liitetty odotuksia niiden tasavertaisuutta edistävistä ja hierarkkisuutta alentavista ominaisuuksista. Kuitenkin niiden käytössä on havaittu myös päinvastaisia vaikutuksia. (Siitonen 2007,145 .) Toisin sanoen ne voivat tuottaa uudenlaista hierarkkisuutta ja epätasa-arvoa. Tasavertaisuutta voi vähentää esimerkiksi se, ettei kaikilla ole samoja teknisiä välineitä käytössään.

Sähköposti on yksi helpoimpia ja käytetyimpiä sähköisen viestinnän muotoja. Sähköpostin käytöllä viestinnässä on havaittu monia etuja. Ensinnäkin viestin lähettäjän ja vastaanottajan ei tarvitse toimia samaan aikaan. Sähköposti 
vapauttaa kirjoittamaan viestejä ja lukemaan niitä silloin, kun siihen on aikaa. Viestit pysyvät sähköpostissa tallessa, joten niitä voi lukea myös useampaan kertaan. Sähköpostin käyttö yleensäkin on helppoa, ja se voi jopa lisätä viestinnän määrää. Varsinkin vaikeista aiheista on joskus helpompi viestiä sähköpostin välityksellä. Sähköposti asettuu puhutun ja kirjoitetun viestinnän välimaastoon. Sillä on sekä informatiivisia että henkilösuhteisiin liittyviä funktioita. (Matikainen 2006, 186; Sivunen 2007, 74-77.)

Johtajan odotetaan myös itse osallistuvan eri teknologioiden käyttöön, mutta hän ei saa olla liian ohjaileva tai johdatteleva. Näennäinen asioiden demokraattinen käsittely voi johtaa konfliktiin, jos osallistujat eivät koe, että heitä on aidosti kuultu. (Parent \& Gallupe 2001, 412-418.) Mikäli pyritään konsensukseen päätöksenteossa, on huomioitava, että sen saavuttaminen kestää pitempään teknologiavälitteisessä vuorovaikutuksessa (Olaniran 1994, 274). Hajautetuissa tiimeissä on havaittu, että mikäli tiimin johtaja ei ole aktiivinen erilaisten viestintävälineiden käyttöönotossa, tiimit joutuvat tyytymään niihin välineisiin, joita on totuttu ennenkin käyttämään (Sivunen 2007, 221). Näin myös verkostossa verkoston johtajan asenne ja halukkuus ottaa käyttöön uusia teknologioita todennäköisesti vaikuttaa.

Kasvokkaisviestinnän arvo on esimerkiksi siinä, että se voi lisätä jaetun informaation määrää (Sivunen 2007, 97). Yksi syy tähän on viestintään osallistuvien tuttuus. Mitä paremmin tunnetaan yhteistyökumppanit, sitä helpompaa viestintä ja informaation jakaminen on. Verkostossa tuttuus ja tuttuuden merkitys rakentunevat eri tavalla teknologiavälitteisessä viestinnässä ja kasvokkaisviestinnässä. Tarjoamalla mahdollisuuksia kasvokkaisviestintään verkoston johtaja voi myös tietoisesti vahvistaa toimijoiden identifioitumista verkostoon, kuten on havaittu hajautetuissa tiimeissä tapahtuvan (Sivunen 2007, 197). Toisaalta kasvokkaistilanteissa muiden keskustelijoiden luoma paine ja kritiikki vaikuttavat enemmän keskustelukumppaneiden mielipiteisiin kuin teknologiavälitteisessä viestinnässä (Olaniran 1994, 274).

Viestintäfoorumeita valitaan joko tarkoituksenmukaisuuden perusteella tai sattumanvaraisesti. Ryhmäviestinnän ja verkostojohtamisen näkökulmasta tietoinen ja tarkoituksenmukaisuuteen pyrkivä foorumien ja viestintäkäytäntöjen valikointi voi olla tarpeen, jos verkostossa halutaan edistää toimijoiden aktiivista osallistumista ja tasavertaisuutta.

\section{STRUKTURAATIOTEORIA}

\section{Vuorovaikutus rakentaa verkoston ja toimintatavat}

Yksi tapa tutkia ryhmiä on kuvata niiden rakennetta. Strukturaatioteoria on evolutionaarinen näkökulma vuorovaikutukseen korostaen rakenteita, jotka vaikuttavat ryhmän näkyvään toimintaan, joka puolestaan voi toistaa, uusintaa ja muuttaa rakenteita sosiaalisissa vuorovaikutusprosesseissa (Gouran 1999, 16). 
Teorian keskeiset käsitteet ovat rakenne, systeemi ja strukturaatio. Systeemitaso edustaa sosiaalista kokonaisuutta näkyvässä muodossa, josta voimme tehdä helposti havaintoja. Verkostossa tätä tasoa edustavat esimerkiksi yhteiset kokoontumistilaisuudet, joissa voi tehdä havaintoja vuorovaikutussuhteista ja sisällöistä. Rakennetaso tarkoittaa sääntöjä ja resursseja, jotka vaikuttavat näkyvän todellisuuden taustalla. Näiden kahden tason suhdetta ja keskinäistä dynamiikkaa kuvaa strukturaatio, joka viittaa prosessiin, jossa ryhmän jäsenet soveltamalla sääntöjä ja käyttämällä resursseja tuottavat ja uudistavat systeemitason järjestelmiä. Strukturaatioon liittyy jännitteitä, joista keskeisiä ovat yksilön ja kollektiivisuuden välinen jännite sekä pysyvyyden ja muutoksen välinen jännite. Jokainen yksilö vaikuttaa strukturaatioprosessiin, muttei yksin vaan yhdessä muiden ryhmän jäsenten kanssa vuorovaikutuksen kautta. Pysyvyyden ja muutoksen välinen jännite syntyy siitä, että strukturaation kautta on mahdollista sekä tuottaa ja vahvistaa edelleen vanhoja rakenteita että uudistaa ja muuttaa niitä. (Poole 1999; Poole, Seibold \& McPhee 1996.) Tämä tarkoittaa sitä, että erilaiset ryhmät - ja minä oletan, että myös verkostot - luovat rakenteensa ja toimintatapansa sosiaalisissa suhteissa ja vuorovaikutuksessa.

Jo lähtökohtaisesti teoria ottaa huomioon kontekstin ja vuorovaikutusprosessit. Teoriaa on sovellettu myös eri viestintäteknologioiden tutkimukseen. Adaptiivisen strukturaatioteorian mukaan teknologian käyttöä tarkastellaan yhteisön tuottamana eikä yksilön valintojen tuloksena. Yhteisön ja teknologian suhde on vastavuoroinen. Sen perusteella voidaan ajatella, että viestintäteknologian käyttö muokkaa verkostoa. (DeSanctis \& Fulk 1999.)

Verkostojen uskotaan tuottavan helposti tehokkuutta ja hyviä tuloksia Linnamaa 2004, 209). Myös organisaatioista on todettu, että niiden jäsenillä on organisaatioiden toimivuuteen vahva usko (Aula 2000, 27). Sama näyttää siis pätevän verkostoihin. Vuorovaikutuksen kannalta on kuitenkin hyvä muistaa, että niin henkilöistä kuin organisaatioistakin koostuvissa verkostoissa suorassa vuorovaikutuksessa kohtaavat aina yksilötoimijat, koska verkosto perustuu henkilökohtaisiin suhteisiin (Niemi-Iilahti 2002, 215). Verkoston toimijoiden tietoisista ja tiedostamattomista valinnoista ja ratkaisuista muodostuvat verkoston toimintatavat. Samalla kun verkostotoimijat pyrkivät toimimaan tietoisesti tavoitteiden hyväksi, he eivät kuitenkaan voi olla täysin tietoisia kaikista toimiensa tuloksista ja vaikutuksista (Littlejohn 2002, 152). Strukturaatioteoriaan nojaten voidaan olettaa, että verkoston rakenne, toimintatavat, vahvuudet ja heikkoudet ovat suoraan suhteessa verkoston vuorovaikutukseen (Gouran 1999). Sen mukaan verkoston toimintatapoihin olisi hyvä kiinnittää tietoisesti huomiota eikä olettaa sen tuottavan automaattisesti hyviä tuloksia.

Ihmisille muodostuu käsitys niiden tuttujen ryhmätilanteiden rakenteista, joissa he ovat mukana (Burr 2004, 77-78). Kun verkostoituminen on ollut vielä uutta tai verkoston toimintatavat eivät ole vielä vakiintuneet, on käsitys verkoston rakenteesta voinut olla epäselvä. Taipumuksemme pyrkiä toimimaan tilanteen edellyttämällä tavalla saa aikaan, että epäselvissäkin tilanteissa ryhmän tai 
tässä tapauksessa verkoston jäsenet pyrkivät luomaan rakenteen ja toimimaan sen puitteissa. Tämä määrittely tapahtuu vuorovaikutuksessa yhteisenä prosessina jäsenten kesken. Roolien vastavuoroisuuden takia kukaan ei voi itse täysin päättää esimerkiksi omaa rooliaan ryhmässä elleivät kaikki määrittele sitä samalla tavalla (Littlejohn 2002, 152-153). Epäselvissä tilanteissa, kun esimerkiksi verkoston toimintatavat eivät ole vielä vakiintuneet, toimijat turvautuvat entuudestaan tuttuihin rakenteisiin ja soveltavat niitä.

Rakennetekijöistä roolit ovat oleellisia kuvaamaan tasavertaisuuden ja johtamisen toteutumista verkostossa. Roolit ovat joukko käyttäytymisen piirteitä, joita niiden haltijoiden odotetaan yksilöinä noudattavan (Pennington 2005, 89). Rooli on tehtävä tai paikka verkostossa, jonka toimija itse ja muut verkoston toimijat tunnistavat ja joka tulee esiin vuorovaikutuksessa. Valmiit roolit otetaan käyttöön vuorovaikutuksessa, uudet roolit syntyvät vuorovaikutuksessa ja vuorovaikutus myös vahvistaa rooleja. Verkoston toimijoiden tasavertaisuutta pohdittaessa roolit ovat kiinnostavia, koska strukturaatioteorian mukaan verkostossa ei voida vain rationaalisesti päättää tasavertaisuuden periaatteesta, vaan sen toteutuminen edellyttää tasavertaisuutta vuorovaikutuksen tasolla ja toimijoiden roolien muovautumista sen mukaan. Tasavertainen osallistuminen edellyttää aktiivisen osallistujan ja vaikuttajan roolia. Ryhmäviestinnän tutkimuksessa erityisesti johtajan rooli on ollut kiinnostuksen kohteena (Valkonen \& Mikkola 2000, 89). Johtaminen puolestaan edellyttää johtajan roolia yhteistyön rakentajana ja yhteistyössä toimijana.

Vanha johtajan roolimalli on voinut edelleen vaikuttaa siihen, ettei johtamista aina pidetä verkostoon sopivana. Verkoston johtaja joutuu todennäköisesti uutta roolia hakiessaan tekemään eroa perinteisen hierarkkisen organisaation johtajan rooliin. Johtajan roolia voi tarkastella esimerkiksi siitä näkökulmasta, ottaako johtaja muut toimijat mukaan päätöksentekoon vai päättääkö hän asioista yksin. Autoritaarinen johtaja tekee päätökset itsenäisesti. Neuvotteleva johtaja konsultoi ryhmän jäseniä, mutta tekee yksin päätöksen. Ryhmäpäätökseen uskova johtaja konsultoi ja selvittää muiden näkemykset ja tekee yksimielisyyteen perustuvan päätöksen. Tärkein päätöksentekomallin valintakriteeri on, tarvitaanko muiden toimijoiden hyväksyntä päätökselle. (Pennington 2005, 137-138.) Ryhmäpäätöksiin pyrkivä johtaja vaikuttaisi olevan lähinnä verkoston tasavertaisuuden ihannetta. Neuvotteleva johtajakin voisi tulla verkostossa hyväksytyksi.

Voi hyvin kuvitella, että verkostossa aktiiviset ja runsaasti puheenvuoroja yhteisissä kokoontumisissa käyttävät jäsenet huomataan ja heille kasautuu johtamiseen liittyviä tehtäviä. Tällaisten verkostotoimijoiden odotetaankin edistävän vuorovaikutusprosesseja, luovan muille toimijoille osallistumismahdollisuuksia ja johtavan päätöksentekoproseduuria. Vuorovaikutussuhteiden ja yhteistyön rakentajana verkoston johtajan rooliin voisi kuulua luontevasti verkoston toimijoiden tasavertaisten osallistumismahdollisuuksien edistäminen yhdessä prosessien laadun arvioinnin ja kehittämisen kanssa. Tästä puolestaan seuraisi, ettei 
johtaminen välttämättä olisikaan uhka tasavertaisuuden ihanteen toteutumiselle verkostossa. Johtamisella ja vuorovaikutusprosessien tietoisella arvioinnilla ja kehittämisellä voidaan pyrkiä varmistamaan toimijoiden keskinäinen tasavertaisuus verkostossa. Tällainen näkemys johtamisesta on luonnollisesti samanlainen ihanne kuin tasavertaisuuskin ja edellyttää paljon sekä johtajalta että muilta verkoston toimijoilta.

\section{FUNKTIONAALINEN TEORIA Johtaja vie verkostoa kohti päämäärää}

Funktionaalisen teorian mukaan johtajan toimintaa voidaan tarkastella hänen toimintojensa ja vuorovaikutustekojensa kautta eli miten hän vuorovaikutusteoillaan pyrkii vaikuttamaan muihin toimijoihin ja tavoitteiden saavuttamiseen. Funktionaalisuus viittaa siis vuorovaikutustekojen vaikuttavuuteen ja siihen, miten vaikutukset suuntautuvat: edistävätkö toiminnot ja teot tavoitteiden saavuttamista vai vaikeuttavatko ne ongelmanratkaisua? (Pavitt 1999, 316.)

Ryhmillä on kaksi perustavanlaatuista päämäärää toiminnassaan: koossa pysymisen päämäärä ja tehtäväkeskeinen päämäärä. Molempien huomioiminen yhdessä on kuitenkin haasteellista. Koossa pysyminen edellyttää ryhmän sisäistä koheesiota, jota vahvistavat positiiviset sosioemotionaaliset vuorovaikutusteot. Tehtäväkeskeinen päämäärä edellyttää siihen keskittyviä toimintoja, esimerkiksi informaation kysymistä tai antamista ja mielipiteiden ilmaisemista. Joskus tehtäväkeskeinen päämäärä edellyttää myös rakentavaa konfliktia, joka lisää jännitteitä ja on siten uhka koheesiolle. Konfliktin välttely koheesion ylläpitämiseksi vaarantaa kuitenkin laadukkaan lopputuloksen tehtävän suorittamisessa. Hyvin toimivat ryhmät onnistuvat tasapainottelemaan tässä jännitteessä. Johtaminen edellyttää kumpaankin keskeiseen päämäärään liittyviä toimintoja. (Pavitt 1999, 316-137.)

Koska koko verkoston olemassaolo perustuu vuorovaikutussuhteiden varaan, voidaan olettaa, että koossa pysymistä edistävät toiminnot ovat tärkeitä verkostokontekstissa. Koheesio voidaan siis nähdä erityisen arvokkaana verkostoympäristössä, vaikka siihen liittyykin riskejä koskien päätöksenteon ja ongelmanratkaisun laatua silloin, jos samanmielisyyttä ja konsensusta korostetaan vastakkaisten näkemysten esille nostamisen kustannuksella. Tosin Pavittin $(1999,318)$ mukaan Rauch ja Behling (1984) kiinnittivät huomiota tutkimuksessaan siihen, että liika koossa pysymisen painotus johtamisessa ei tyydytä ryhmän jäseniä silloin, kun se koetaan tarpeettomaksi ja jopa esteeksi päämäärän saavuttamisessa.

Funktionaalinen näkökulma korostaa myös sitä, miten tiettyjen vaiheiden kautta ryhmän päätöksentekoprosessi tuottaa laadukkaita päätöksiä ja tuloksia. Sen mukaan ryhmän tulee 
1. päätyä yhteisymmärrykseen päätöksenteon tavoitteesta

2. määritellä etukäteen kriteerit hyväksyttävissä olevalle ratkaisulle

3. kartoittaa realistiset ja kriteerit täyttävät päätöksenteon vaihtoehdot

4. arvioida vaihtoehdot

5. valita vaihtoehdoista parhaiten kriteerit täyttävä.

(Gouran \& Hirokawa 1996, 56-57; Littlejohn 2002, 266-267.)

Myös päätöksentekoprosessin läpivieminen edellä kuvattujen vaiheiden mukaan edellyttää johtamista. Päätöksentekoprosessi on verkostossa erityisen haasteellinen, jos siinä pyritään varmistamaan sekä tulosten laatu että jäsenten tasavertainen osallistuminen. Verkostossa vuorovaikutus toteutuu monilla eri foorumeilla. Eri rooleissa olevat verkoston toimijat pääsevät vaikuttamaan todennäköisesti päätöksentekoprosessiin eri tavalla ja eri vaiheissa. Päätöksenteon keskittyneisyys tai hajautuneisuus vaikuttaa myös koheesioon (Brown 2000).

Funktionaalinen teoria korostaa siis verkostojohtamisessa ja verkoston vuorovaikutuksessa verkoston tuloksellisuuteen vaikuttavia tekijöitä. Vaikka koheesiolla on välillisesti merkitystä tuloksellisuuden kannalta, vaikuttaa siltä, ettei teorialla ole annettavaa verkoston tasavertaisuuden näkökulmasta. Toisaalta jos tasavertaisuus on verkostossa tärkeä arvo, tuloksellisuus voi nimenomaan edellyttää sen huomioimista. Tasavertaisuutta voi tarkastella myös yhtenä verkostotoiminnan tuloksena, jolloin huomio kiinnittyykin siihen, millä toiminnoilla sitä voidaan edistää. Funktionaalinen teoria painottaa kontekstia vähemmän kuin strukturaatioteoria, mutta soveltuu hyvin johtamistilanteisiin sekä ongelmanratkaisu- ja päätöksentekotilanteisiin.

Myös funktionaalista teoriaa voisi soveltaa verkostotutkimuksessa analysoitaessa teknologiavälitteistä viestintää ja vuorovaikutusta. Erityisen panoksensa teoria voisi tuoda verkostojohtamisen analysointiin teknologiavälitteisinä vuorovaikutustekoina. Ryhmäpäätöksentekoprosessien kehittäminen eri teknologioiden tukemina voi olla verkostojen tulevaisuuden haaste. Myös sen alueen tutkimukseen funktionaalinen teoria soveltuu ja tuloksia voitaisiin soveltaa muihinkin virtuaalisiin päätöksentekotilanteisiin.

\section{LOPUKSI}

Moderni verkostoituminen on vielä varsin uusi yhteistyön muoto. Siksi verkostoissa vielä haetaan parhaiten sopivia toimintatapoja. Verkostojohtamista on tarjottu ratkaisuksi verkostoissa havaittuihin ongelmiin ja verkostotoiminnan kehittämiseen. Lähtökohtaisesti ryhmäviestinnän näkökulma verkostotutkimuksessa on luonteva, koska verkosto perustuu toimijoiden välisiin suhteisiin ja vuorovaikutukseen.

Tärkeimmiksi osa-alueiksi verkoston johtamisessa tässä artikkelissa nousivat toimintatapojen arviointi ja kehittäminen, toimijoiden vuorovaikutuksen 
edistäminen ja osallistumismahdollisuuksien varmistaminen, uusien toimijoiden innostaminen mukaan verkostoyhteistyöhön sekä päätöksentekoprosessin ohjaaminen. Tärkeää on myös verkostojohtajan oma vuorovaikutus ja viestintä.

Strukturaatioteorian ja funktionaalisen teorian tarkastelu rinnakkain osoittaa, että teoriat näyttävät verkoston erilaisena. Funktionaalinen teoria korostaa johtajan kahtalaista haastetta: toisaalta vahvistaa koheesiota, toisaalta varmistaa hyvä päätöksentekoprosessi. Se painottaa vuorovaikutuksen suhdetta verkoston tuloksellisuuteen. Strukturaatioteoria korostaa puolestaan vuorovaikutuksen suhdetta verkoston rakenteeseen ja toimintatapoihin. Strukturaatioteoria johdattaa tarkastelemaan verkostotoimijoiden rooleja ja niiden suhdetta esimerkiksi tasavertaisuuden toteutumiseen verkostossa.

Strukturaatioteoria vaikuttaa ylipäätään soveltuvan hyvin verkostokontekstiin, mikä ei ole sinänsä yllättävää, sillä onhan sen kehittäjä, Anthony Giddens, pyrkinyt luomaan siitä sosiaalisen toiminnan yleisteorian (Littlejohn 2002, 152). Jo lähtökohtaisesti teoria ottaa huomioon kontekstin. Strukturaatioteorialla voidaan myös selittää, miten verkoston toimintatavat syntyvät, minkälaisia rooleja syntyy ja mitä niistä seuraa edelleen verkoston vuorovaikutukselle ja toiminnalle. Roolien tarkastelussa on johtajaroolin lisäksi yhtä mielekästä kiinnittää huomiota muiden verkostotoimijoiden rooleihin, koska jokainen vaikuttaa prosesseihin. Verkoston johtaja voi olla avainasemassa varmistamassa tasavertaisuuden toteutumisen verkoston sisäisissä prosesseissa. Johtaminen ei siten välttämättä ole ristiriidassa toimijoiden keskinäisen tasavertaisuuden kanssa. Jokaisen toimijan omaa vastuuta pitää kuitenkin korostaa myös sen suhteen, että toimijat omaksuvat aktiivisen osallistujan roolin.

Funktionaalinen teoria ei lähesty ryhmäilmiöitä yhtä kokonaisvaltaisesti kuin strukturaatioteoria, esimerkiksi konteksti jää vähemmälle huomiolle. Verkostojohtamisen kannalta sillä voisi olla kuitenkin paljon annettavaa verkostotutkimukselle. Teoria on vahvimmillaan johtamis- ja päätöksentekotilanteiden yhteydessä. Sitä kaivattaisiin esimerkiksi selittämään, millaiset tekijät vaikuttavat verkoston tuloksellisuuteen.

Uskon, että näitä molempia ryhmäviestinnän klassikkoteorioita tullaan vielä soveltamaan verkostotutkimuksessa. Kumpaakin teoriaa voisi soveltaa verkostokontekstissa esimerkiksi, kun tutkitaan viestintäteknologioiden hyödyntämistä verkoston päätöksentekoprosesseissa. Ajan ja paikan rajat ylittävät teknologiat voisivat olla tukemassa verkostotoimijoiden tasavertaista osallistumista, jos verkostoissa niin halutaan. Viestintäteknologioita kannattaa tutkia myös siitä näkökulmasta, miten funktionaalisen näkökulman mukainen päätöksentekoprosessi on siirrettävissä teknisiin viestintävälineisiin ja virtuaalisille viestintäfoorumeille. Nämä tutkimusalueet herättävät myös uusia kysymyksiä verkostojohtamisesta: esimerkiksi miten verkostojohtaminen tulee näkyväksi teknologiavälitteisessä viestinnässä ja millaista on teknologiavälitteinen verkostojohtaminen. 


\section{KIRJALLISUUS}

Amy, A. H. 2008. Leaders as facilitators of individual and organizational learning. Leadership \& Organization Development Journal 29 (3), 212-234.

Aula, P. 1999. Organisaation kaaos vai kaaoksen organisaatio? Helsinki: Lokikirjat.

Aula, P. 2000. Dynaaminen duo: organisaation kulttuurit ja viestintä. Teoksessa P. Aula \& S. Hakala (toim.) Kolmet kasvot: näkökulmia organisaatioviestintään. Helsinki: Lokikirjat, 27-49.

Brown, R. 2000. Group processes. Oxford: Blackwell.

Burr, V. 2004. Sosiaalipsykologisia ihmiskäsityksiä. Suom. J. Vainonen. Tampere: Vastapaino.

Castells, M. 1996. The rise of the network society - the information age: economy, society and culture. Oxford: Blackwell.

DeSanctis, G. \& Fulk, J. 1999. Conclusion: research issues and directions. Teoksessa G. DeSanctis \& J. Fulk (toim.) Shaping organization form: communication, connection and community. Thousand Oaks: Sage, 497502.

Galanes, G. J., Adams, K. \& Brilhart, J. K. 2004. Effective group discussion: theory and practice. 11. painos. New York: McGraw-Hill.

Gentry, W. A., Harris, L. S., Baker, B. A. \& Leslie J. B. 2008. Managerial skills: what has changed since the late 1980s. Leadership \& Organization Development Journal 29 (2), 167-181.

Giddens, A. 1983. Comments on the theory of structuration. Journal for the Theory of Social Behaviour 13 (1), 75-80.

Gouran, D. S. 1999. Communication in groups: the emergence and evolution of a field of study. Teoksessa L. R. Frey, D. S. Gouran \& M. S. Poole (toim.) The handbook of group communication: theory and research. Thousand Oaks: Sage, 3-36.

Gouran, D. S. \& Hirokawa, R. Y. 1996. Functional theory and communication in decision-making and problem-solving groups: an expanded view. Teoksessa R. Y. Hirokawa \& M. S. Poole (toim.) Communication and group decision making. Thousand Oaks: Sage, 55-80.

Hakanen, M., Heinonen, U. \& Sipilä, P. 2007. Verkostojen strategiat: menesty yhteistyössä. Helsinki: Edita.

Hannus, J. 1997. Prosessijohtaminen: ydinprosessien uudistaminen ja yrityksen suorituskyky. 4. painos. Jyväskylä: Gummerus.

Hautamäki, A. 2001. Suomi muutosten edellä: raportti Suomen haasteista. Sitran raportteja 6. Kuopio: Kevama.

Hujala, A. 2008. Johtamisen moniäänisyys: johtaminen vuorovaikutuksena ja puhuntana hoivayrityksissä. Kuopio: Kuopion yliopisto.

Huotari, M.-L., Hurme, P. \& Valkonen T. 2005. Viestinnästä tietoon: tiedon luominen työyhteisössä. Helsinki: WSOY.

Karriker, J. H. 2005. Cyclical group development and interaction-based leadership emergence in autonomous teams: an integrated model. Journal of Leadership and Organizational Studies 11 (4), 54-64. 
Katz, N., Lazer, D., Arrow, H. \& Contractor, N. 2004. Network theory and small groups. Small Group Research 35, 307-332.

Kickert, W. J. M., Klijn, E.-H. \& Koppenjan, J. 1997. Managing complex networks: strategies for the public sector. Lontoo: Sage.

Kickert, W. J. M. \& Koppenjan, F. M. 1997. Public management and network management: an overview. Teoksessa W. J. M. Kickert, E.-H. Klijn \& J. F. M. Koppenjan (toim.) Managing complex networks: strategies for the public sector. Lontoo: Sage, 35-61.

Kotter, J. P. 1996. Muutos vaatii johtajuutta. Suom. M. Tillman. Helsinki: Rastor.

Linnamaa, R. 2004. Verkostojen toimivuus ja alueen kilpailukyky. Tampere: Cityoffset.

Littlejohn, S. W. 2002. Theories of human communication. 7. painos. Belmont, Wadsworth.

Matikainen, J. 2006. Vuorovaikutus ja sosiaalisuus verkostossa. Teoksessa P. Aula, J. Matikainen \& M. Villi (toim.) Verkkoviestintäkirja. Helsinki: Yliopistopaino, 177-195.

Mattila, M. \& Uusikylä, P. 1999. Mitä on verkostoanalyysi? Teoksessa M. Mattila \& P. Uusikylä (toim.) Verkostoyhteiskunta: käytännön johdatus verkostoanalyysiin. Helsinki: Gaudeamus.

McNeill, J. R. \& McNeill, W. H. 2006. Verkottunut ihmiskunta: yleiskatsaus maailmanhistoriaan. Suom. N. Vilokkinen. Tampere: Vastapaino.

Niemi-Iilahti, A. 2002. Verkostoparadigma ja implementaatio. Hallinnon Tutkimus 3, 209-220.

Olaniran, B. 1994. Group performance in computer-mediated and face-to-face communication media. Management Communication Quarterly 7 (3), 256281.

Parent, M. \& Gallupe, R. B. 2001. The role of leadership in group support systems failure. Group Decision and Negotiation 10, 405-422.

Pavitt, C. 1999. Theorizing about the group communication-leadership relationship. Teoksessa L. R. Frey, D. S. Gouran \& M. S. Poole (toim.) The handbook of group communication: theory and research. Thousand Oaks: Sage, 313-334.

Pehkonen, A. 2004. Kylä kutsuu: tutkimus tulomuuttoprosesseista maaseudulle. Turku: Siirtolaisuusinstituutti.

Pennington, D. C. 2005. Pienryhmän sosiaalipsykologia. Suom. M. Ahokas. Helsinki: Gaudeamus.

Poole, M. S. 1999. Group communication theory. Teoksessa L. R. Frey, D. S. Gouran \& M. S. Poole (toim.) The handbook of group communication: theory and research. Thousand Oaks: Sage, 37-70.

Poole, M. S., Seibold, D. R. \& McPhee, R. D. 1996. The structuration of group decisions. Teoksessa R. Y. Hirokawa \& M. S. Poole (toim.) Communication and group decision making. Thousand Oaks: Sage, 114-146.

Rasimus, A. 2006. Uudet liikkeet: radikaali kansalaisaktivismi 1990-luvun Suomessa. Tampere: Tampereen yliopistopaino. 
Rauch, C. F. Jr. \& Behling, O. 1984. Functionalism: basis for an alternative approach to the study of leadership. Teoksessa J. G. Hunt, D.-M. Hosking, C. Schriesheim \& R. Stewart (toim.) Leaders and managers: international perspectives on managerial behavior and leadership. New York: Pergamon, 45-62.

Ritter, Th. \& Gemünden, H. G. 2003. Network competence: its impact on innovation success and its antecedents. Journal of Business Research 56, $745-755$.

Ruostetsaari, I. 2003. Valta muutoksessa. Helsinki: WSOY.

Schaap, L. \& Van Twist, M. J. W. 1997. The dynamics of closedness in networks. Teoksessa W. J. M. Kickert, E.-H. Klijn \& J. F. M. Koppenjan (toim.)

Managing complex networks: strategies for the public sector. Lontoo: Sage, $62-78$.

Siitonen, M. 2007. Social interaction in online multiplayer communities. Jyväskylä Studies in Humanities 74. Jyväskylä: Jyväskylän yliopisto.

Sivunen, A. 2007. Vuorovaikutus, viestintäteknologia ja identifioituminen hajautetuissa tiimeissä. Jyväskylä Studies in Humanities 79. Jyväskylä: Jyväskylän yliopisto.

Stacey, R. 1991. The chaos frontier: creative strategic boundaries between order and chaos in organizations. San Francisco: Jossey-Bass.

Uusikylä, P. 1999. Verkosto valintana. Teoksessa P. Virtanen (toim.) Verkostoituva asiakastyö. Helsinki: Kirjayhtymä, 47-70.

Valkonen, T. \& Mikkola, L. 2000. Miten analysoida tehtäväkeskeisen ryhmän vuorovaikutusta? Teoksessa M. Valo (toim.) Nykytietoa puheviestinnän opetuksesta. Jyväskylän yliopisto. Viestintätieteiden julkaisuja 20, 86-108.

Vanhala, S., Laukkanen, M. \& Koskinen, A. 2002. Liiketoiminta ja johtaminen. 3. painos. Keuruu: KY-Palvelu.

Viitala, R. 2004. Henkilöstöjohtaminen. Helsinki: Edita.

Virkkala, S. 2002. Paikallinen kehittäminen naisnäkökulmasta - kokemuksia Devote-projektista. Kokkola: Jyväskylän yliopisto, Chydenius-Instituutti.

Virtanen, P. 1999. Verkostoista voimaa. Teoksessa P. Virtanen (toim.) Verkostoituva asiakastyö. Helsinki: Kirjayhtymä, 33-46. 